1. Introdução;

2. Conceitos de mercado;

3. Dimensão socioculturais de mercado;

4. A ampliação do conceito de mercado;

5. O mercado e o desenvolvimento;

6. O mercado moldador de valores;

7. O mercado como padrão do avanço;

8. Ponderaçôes sobre conceito de conflito;

9. O mercado como conciliador de conflitos;

10. O mercado como regulador e multiplicador de

informaçōes;

11. O mercado como fonte discernidora para o

consumo;

12. O mercado como pólo de mudanças sociais; 13. Considerações finais,

\section{0 mercado como catalisador do desenvolvimento}

Raimar Richers

"Se todas as formas de trabalho e comércio pudessem ser comandadas pelo mercado, estariamos bem melhor". (William Ouchi, 1984, p. 28)

\section{INTRODUÇÃO}

No mercado acontecem coisas que percebemos apenas superficialmente, mas que podem exercer profunda influência sobre a nossa formação cultural e social.

Exemplifiquemos o que tenho em mente: ao entrarmos numa loja como comprador potencial, captamos rapidamente uma ampla gama de impressões que se impõem aos nossos sentidos, como forma de cores da decoração, a variedade e disposição das mercadorias, 0 trajar e comportamento dos balconistas, o preço de algum produto remarcado, talvez também a música ambiental, ou até o cheiro caracterísitco que nos atrai ou repele. Mas a maneira como tudo isto foi preparado pela gerência da loja dificilmente nos interessa, apesar de exercer uma forte influência sobre a nossa decisão de comprar ou não. Menos ainda nos preocupa a multiplicidade de processos, seja por parte dos seus produtores, seja pelo próprio lojista.

No entanto, para que um "mercado", como aquela loja, possa ser bem-sucedido, todas estas variáveis, perceptíveis ou não, conscientes ou inconscientes, precisam formar um conjunto harmonioso e condizente com as . expectativas que o lojista alimenta em relação a nós, seus clientes potenciais.

Mais ainda: o nosso contato normalmente regular e intenso com o mercado (no seu sentido lato, isto é, não só em lojas, mas também através de leitura de jornais e revistas, do acompanhamento dos meios de comunicação eletrônicos e das trocas de idéias com amigos e parentes sobre produtos e serviços) exerce marcante influência sobre o nosso sistema de valores e, por conseguinte, contribui para a formação de nossa personalidade, nossos gostos e hábitos.

O que pretendo transmitir através deste é uma idéia que, apesar de simples e de amplo significado, até não recebeu quase nenhuma atenção dos pesquisadores sociais: a de que as funções do mercado são bem mais amplas do que normalmente se lhe atribui, sobretudo quanto à sua influência sobre os processos de mudança social e de evolução dos estilos de vida. A tese central que deriva desta interpretação e que constitui a principal mensagem deste artigo pode ser assim resumida: o mercado éo principal catalisador do desenvolvimento econômico e social de uma nação capitalista. Ele é o "ponto de encontro" predominante das forças de uma sociedade, que não só viabiliza as transações de bens e serviços, como exerce também forte influência sobre $a$ formação e a evolução do sistema de valores dos consumidores, ao expô-los a situações que afetam os seus processos de aprendizagem. Neste sentido, o mercado rivaliza, e fortemente, com os principais focos de mudança social em que os sociólogos costumam concentrar a sua atenção, como a família, a escola, os "pares" e os agentes de mudança.

Os caminhos que pretendo percorrer aqui, para prestar apoio a esta colocação, são os seguintes:

1. uma breve revisão dos principais conceitos de mercado;

2 . a proposição de uma nova definição, mais abrangente;

3. uma discussão das principais implicações da definição proposta; e

4 considerações sobre as relações entre o mercado e o desenvolvimento de uma nação. ${ }^{1}$

Os dois últimos desses tópicos serão abordados através da formulação de sete hipóteses que submeto à apreciação de pesquisadores sociais $\mathrm{\epsilon}$ mercadológicos para testes empíricos. 


\section{CONCEITOS DE MERCADO}

A evolução dos conceitos costuma acompanhar de perto as mudanças dos fenômenos a que se referem. Por vezes antecipa-se um pouco a estas mudanças, por vezes atrasa-se. Quando os conceitos defasam-se em relação à realidade, precisam ser reavaliados. É este, quer me parecer, o caso do mercado. O nosso entedimento a seu respeito passou por vários estágios ao longo dos séculos, mas parece ter estagnado há tempos, apesar das profundas transformações que o afetaram ultimamente.

Até agora o mercado tem sido enfocado sob quatro ângulos distintos, a saber:

- como local onde se realizam trocas entre compradores e vendedores: a ênfase, neste caso, está no aspecto físico e comercial;

- como mecanismo de formação dos preços: é esta a abordagem dos economistas;

- como meio de transferência de posse: que corresponde à visão legal;

- como meio para conquistar clientes: conforme a interpretação do marketing.

O primeiro destes enfoques, que enfatiza o local físico, é o mais comum e divulgado. Ele vem de longa data, da fase pré-industrial, quando tanto a produção quanto o comércio eram realizados em pequenos núcleos geográficos, que mantinham nenhum ou muito pouco contato entre si. A casa era o centro produtivo e de consumo de cada família e o campo supridor da maioria das matérias-primas e dos alimentos necessários à sobrevivência. Nas vilas, cada domicílo especializava-se na produção artesanal de algum bem essencial para a família e seus vizinhos mais próximos, tais como tecidos, pão, sapatos, ferraduras, vestimentas etc. Antes do advento do dinheiro como meio circulante, esses bens eram diretamente intercambiados. Normalmente, o comprador procurava o vendedor e encomendava produtos, conforme seus desejos e especificações.

Com o tempo, todavia, os próprios agricultores e artesãos "descobriram" as vantagens de of erecerem seus produtos num mercado aberto e competitivo. Surgiram as feiras, as lojas e comércio móvel entre comunidades, através de transportes por carroças ou vias fluviais e marítimas. Mais tarde, desenvolveram-se formas sofisticadas de comércio, que demandavam a presença de um intermediário entre os vendedores (produtores) e os compradores (consumidores), como as bolsas de mercado e as empresas de comércio inter-regional e internacional. Apesar de todas essas transformações, $o$ mercado continuou a ser encarado primordialmente como um local ou ponto de encontro entre partes interessadas em efetuar trocas.

A Revolução Industrial provocou uma ampliação considerável deste conceito físico do mercado, graças às inovações tecnológicas (como a máquina a vapor, 0 tear automático e o telégrafo), a divisão do trabalho e, mais tarde, a massificação dos sistemas de produção e de distribuição. Graças a essas mudanças estruturais, não só os custos unitários de produção puderam ser consideravelmente reduzidos, como também ampliou-se a cobertura geográfica dos mercados. Em contrapartida, os riscos da formação de estoques aumentaram, na medida em que os bens eram predominantemente produzidos em série e não mais por encomenda, para tirar proveito das crescentes economias de escala. Ao mesmo tempo e à medida que os mercados expandiam-se, aumentava a intensidade da concorrência e, com isto, surgiu uma nova interpretação do mercado como centro de formação dos preços. ${ }^{2}$

Citemos uma passagem de um autor, Alfred Marshall (1982, p. 186), que se destacou entre os economistas clássicos como o principal protagonista intelectual do processo de industrialização: "Num certo sentido, a totalidade do mundo ocidental pode ser considerada como único mercado para muitos tipos de títulos e de bolsas de valores, para muitos metais preciosos e, em menor proporção, para a lã, o algodão e até o trigo ... Em todos esses casos, as despesas de transporte, incluindo as taxas alfandegárias, não são suficientes para impedir que compradores em todas as partes do mundo ocidental venham a competir entre si para oferecer os mesmos tipos de bens." Claramente, até o limiar do século $\mathrm{XX}$, não mais os núcleos urbanos, mas o próprio mundo passou a ser considerado o cenário apropriado para o mercado, graças à quase explosiva evolução do comércio regional e internacional. Isto permitiu que alguns grandes pensadores liberais, como Adam Smith e Alfred Marshall, revolucionassem o conceito tradicional de mercado, que deixou de ser mero conjunto de locais, tornando-se sobretudo um mecanismo encarregado de equacionar as forças oponentes da oferta e da demanda, para assegurar a manutenção do equilíbrio na formação dos preços. A partir deste mecanismo, o mercado passa a ser um símbolo, parcialmente abstrato, de realização de uma das maiores ambições do homem: a de encontrar a sua liberdade ecônomica e, através dela, a justiça social.

A terceira das interpretações do mercado, a legal, é mais restrita de todas, embora tenha acrescentado algo de significativo ao conceito. Ela realça a transferência de posse, quando da realização de uma troca formal entre comprador e vendedor. Assim, na definição de Narver e Savitto (1971, p. 57), o mercado é o "o contrato entre quem procura (compradores ou adquirentes) e quem oferece (vendedores ou cedentes) para transferir a propriedade ou o uso do direito para com um fator, bem ou serviço". Este conceito enriquece a visão do mercado, ao focalizar o aspecto contratual de uma transação, que protege os interesses e direitos mútuos dos partidos, graças à troca de um documento ou título de posse que simplifica a negociação e antecipa-se ao ato físico de transação dos bens, ampçliando e acelerando, com isso, as oportunidades de intercâmbio comercial, sem ampliação substancial dos riscos. Todo o comércio beneficia-se desta vantagem, que se torna tão mais importante quanto mais distantes estão os compradores de seus vendedores. O melhor exemplo é o comércio internacional, onde praticamente inexistem as vendas à vista: tudo é feito à base de contratos, antes que a mercadoria seja expedida.

Uma quarta visão, mais recente, do mercado foi dada pelos homens de marketing, a partir de sua preocupação em compreender as forças que, além do preço, 
fazem com que um produto ou serviço possa ser transacionado no mercado. Kotler (1974, p. 139), por exemplo, fala dos "quatro os de qualquer mercado", a saber:

- Objetos de compra: o que o mercado compra?

- Objetivos de compra: por que ele compra?

- Organização para compra: quem compra?

- Operações da organização de compra: como ele compra?

O enfoque de marketing é pragmático - isto é, voltado a resultados operacionais de interesse para as empresas - o que o torna demasiadamente denso e limitativo para os fins mais especulativos de uma ciência. O próprio Kloter (1984, p. 7), aceita implicitamente esta limitação ao definir: "Um mercado é como o conjunto de compradores reais e potenciais de um produto'. Isto conduz a perguntas tais como: $E$ os vendedores, onde ficaram? Ou: E o dinamismo do conflito criativo entre compradores e vendedores, onde ficou?

A ênfase que o homem de marketing dá ao comprador decorre de sua preocupação em fazer o empresário dirigir suas atenções para o mercado e usá-lo como ponto de referência para todas as suas decisões estratégicas. Marketing, por enquanto, ao menos, não é uma ciência, mas um instrumento destinado a facilitar os objetivos comerciais de uma empresa. Daí a ausência explícita do vendedor na definição de Kolter (e de outros mercadólogos). $O$ vendedor está automaticamente presente, através da figura da própria empresa que busca o seu mercado e seus compradores potenciais para satisfazer os seus objetivos de rentabilidade, aumento de participação ou quaisquer outros.

Em suma, temos quatro conceitos, cada um focalizando aspectos específicos do mercado que não são conflitivos entre si. Conjugando-os, poder-se-ia dizer que hoje entende-se por mercado tanto um local ou conjunto de locais de compra e venda, quanto um sistema de preços à busca de equilíbrio, como também um mecanismo de proteção mútua entre compradores e vendedores e, finalmente, um enfoque administrativo que a empresa pode utilizar para incentivar os seus negócios.

\section{DIMENSÕES SÓCIO-CULTURAIS DOMERCA- DO}

Como estas quatro interpretações são distintas, mas não conflitivas entre si, e como se referem ao mesmo fenômeno, visto de ângulos diferentes, impõe-se a idéia de que nenhuma delas é suficientemente ampla para oferecer uma caracterização satisfatória deste fenômeno. De fato, o mercado moderno exerce muito mais funções do que cada uma das quatro dimensões, e mesmo o seu conjunto, sugere.

Numa Sociedade industrial, como a nossa, uma multiplicidade de forças convergem para o mercado e são por ele absorvidas e transformadas para serem "devolvidas" à sociedade sob novas formas e roupagens. Acima de tudo, o mercado moderno é um catalisador sócio-cultural que absorve, armazena e divulga informações e, através disto, exerce múltiplos papéis sócioculturais que ainda não foram submetidos a uma aná- lise criteriosa por parte de qualquer uma das disciplinas do conhecimento humano.

Isto se deve provavelmente a duas limitações. Uma delas são as fronteiras que cada disciplina impõe-se para não se perder no espaço. Assim, por exemplo, as ciências econômicas convencionaram aceitar o pressuposto cômodo, mas altamente discutível, de que o comportamento do homem é sempre racional quando se dirige ao mercado. Supostamente ele sabe como maximizar a sua relação custo/benefício, ou é capaz e está sempre disposto a procurar atingir o máximo de satisfação de seus desejos, dentro dos limites de sua renda disponivel para compra de bens de consumo. Se não o consegue, é porque a concorrência entre produtores é imperfeita, e não porque ele seja emotivo, despreparado ou até indiferente ao atingimento da otimização de suas necessidades. $O$ economista assume o risco dessa simplificação, em parte porque considera que qualquer "variação" comportamental em torno da "média" racional não cabe ser analisado por sua disciplina, em parte porque isto lhe permite equacionar a relação entre oferta e demanda como um fenômeno matematicamente mensurável e projetável. A outra limitação parece-me mais simples: até hoje, as disciplinas pre- destinadas a analisar o mercado como um fenômeno comportamental como a sociologia, a psicologia social e a economia do desenvolvimento - não se interessaram pelo assunto.

Provavelmente, a principal decorrência deste processo de simplificação e esquecimento ¿́ que, na maioria das vezes, o mercado é pensado a partir das relações comerciais de troca. Sob o ponto de vista comercial, o mercado é, acima de tudo, um ponto de convergência entre as posições, em princípio antagônicas, mas mutuamente interessadas, do vendedor e do comprador. Inegavelmente, o que conduz as partes ao mercado costumam ser motivações de ordem material ou comercial, mas o que resulta dos intercâmbios e, sobretudo, a busca de relações sistemáticas através do mercado, excede de longe o âmbito comercial.

Suponho que estas relações "extracomerciais"' sejam predominantemente comportamentais e educacionais e que contribuam à socialização dos indivíduos. ${ }^{4}$ Uma pessoa ou instituição exerce uma influência, por vezes profunda, sobre outras pessoas ou grupos e, através desta influência, criam-se e divulgam-se valores e hábitos que fazem parte da formação das personalidades e dos estilos de vida de uma sociedade. ${ }^{5} \mathrm{~A}$ essência deste processo é o que se costuma chamar, algo vagamente, de formação cultural que, no nível individual, realiza-se através da aprendizagem, e no nível grupal, através da influência de lideres de opinião e dos sistemas de comunicação. ${ }^{6} \mathrm{O}$ conjunto destas variáveis psicológicas e sociais conduzem à mudança social e esta exerce uma influência, por vezes acentuada, nos processos de desenvolvimento de uma nação. ${ }^{7}$

Apesar de sua enorme complexidade, a natureza e mesmo a inter-relação entre as variáveis psicossociais mencionadas no parágrafo anterior são hoje razoavelmente bem compreendidas, quanto aos seus aspectos individuais e grupais relacionadas com a formação da personalidade e dos valores. ${ }^{8}$ As pesquisas têm sido intensas e bastante reveladoras nesta área. Mas, até o momento, elas atribuíram pouca atenção a aspectos insti- 
tucionais, como, por exemplo, as influências exercidas por grandes concentrações sociais e políticas sobre os indivíduos e grupos, vice-versa. O Estado moderno mereceria esta atenção, bem como a empresa, o sistema de comunicação eletrônica - e certamente o mercado.

\section{A AMPLIAÇÃO DO CONCEITO MERCADO}

Cabe, portanto, a pergunta: qual é o papel que o mercado exerce nos processos de mudança social e como isto afeta o desenvolvimento de um país em formação? $\mathrm{Pa}$ ra responder a esta questão precisamos, primeiro, ampliar o conceito de mercado, buscando uma definição mais condizente com as transformações que ocorreram ao longo do presente século e que, ao mesmo tempo, leve em conta sua característica de núcleo de mudanças sociais e de catalisador do desenvolvimento. Ademais, convém que esta interpretação não procure substituir os outros quatro conceitos já abordados, pois todos eles continuam válidos como caracterização parcial do fenômeno mercado.

Buscando atender a estas condições, definimos mercado como qualquer oportunidade institucionalizada de contato humano par realizar trocas. Vejamos como interpretar esta definição.

A finalidade precípua do mercado é facilitar as trocas entre pessoas físicas e/ou jurídicas. A troca, portanto, é umą faceta obrigatória do conceito de mercado. Mas não é a gama inteira das trocas que faz parte do conceito: ela deve ser restrita, primeiro, ao intercâmbio entre humanos (e não, por exemplo, incluir as mutações biológicas provocadas por contatos entre células); segundo, deve envolver algum meio (físico ou não) que facilite o contato entre as pessoas ou organizações interessadas em trocar; e, terceiro, deve ser mais do que um acontecimento esporádico, mas, pelo contrário, ser algo que as pessoas e/ou instituições procuram porque sabem que "ali" poderaõ encontrar condições para realizar uma troca. (Ou seja: o encontro casual de dois amigos que conduz a um cordial bate-papo é uma troca, mas não dentro do contexto de mercado, por ser esporádico e não intencional).

Não é preciso que este algo a que as pessoas se dirigem seja um local físico (como uma feira, ou uma loja); pode ser também um meio de comunicação (como o telefone, um congresso ou um satélite). Também não é conceitualmente necessário que a troca envolva um objeto ou serviço; pode referir-se a uma idéia, uma informação ou qualquer coisa que prezemos o suficiente para abrir mão de alguma outra casa, para obtê-la. Finalmente, não é importante para o conceito de mercado se a troca efetivamente se realiza ou não. Basta que haja uma oportunidade de contato suficientemente conhecida pelos "vendedores" e "compradores" para que ela se dirijam quando desejam realizar trocas. Com o tempo, essa oportunidade transforma-se num hábito institucionalizado entre entendidos no assunto da troca. $O$ mercado, portanto, é um ponto de encontro, não necessariamente tangível, que é regularmente procurado por interessados que buscam trocar valores entre si. Para que ele possa existir e crescer, devem prevalecer as seguintes condições:
- pelo menos duas partes (pessoas e/ou instituições) devem estar interessadas no processo de troca);

— ambas têm o desejo de trocar algo tangível ou não;

- ambas vêem vantagem para si ao realizar a troca;

- qualquer uma das partes pode rejeitar a proposta da outra e ambas estão cientes e aceitam esta condição;

- ambas estão dispostas a cumprir a sua parte do compromisso e estão em condições de fazê-lo;

- ambas buscam o contato através de um "meio" que consideram propício para facilitar sua mútua aproximação.

É este meio que representa o mercado. Deles sabemos, por experiência ou através de informações, que é o instrumento adequado para realizar trocas. O que forma o mercado, portanto, é o hábito daqueles que o procuram; é o ciclo do mesmo tipo de intercâmbio que se processa e divulga entre os interessados e os atrai para realizar e repetir atos de troca. Quanto mais interessados se sentirem atraídos por aquele meio, tanto mais rapidamente ele se desenvolverá.

Em larga escala, as trocas no mercado são de natureza comercial. Há uma infinidade de situações que refletem esse tipo de relação econômica entre compradores e vendedores, locatários e locadores, credores e devedores, empregados e empregadores, fornecedores e usuários, domicílios e empresas, etc.

Mas o mercado não se esgota na realização das transações comerciais. Dentro do contexto mais amplo aqui proposto, ele inclui também qualquer outra oportunidade de troca cabível na definição, como, por exemplo, uma sala de concertos, um congresso de médicos, museus, escolas, partidos políticos, associações de classe, sindicatos, missões culturais ou qualquer outra modalidade de contato mais ou menos regular entre membros de uma sociedade que desejam trocar valores entre si, envolva isso dinheiro ou não. Assim, tanto o padre que sobre o púlpito de uma igreja quanto o político que faz um discurso em um palanque são pessoas à busca de troca e, por conseguinte, pertencem a algum tipo de mercado. O importante, nestes casos, não é se esta troca implica recursos materiais ou monetários, mas que haja um encontro entre pessoas que desejam intercambiar algo de valor recíproco.

Também os instrumentos de troca tornam-se mais amplos e multiformes se encararmos o mercado sob ângulos que transcendem o âmbito comercial. Eles certamente incluem as formas usuais do comércio, como inspeção, amostragem, descrição de produtos e serviços, catálogos, listas de preços, folhetos, fatura, cheque e a própria moeda. Mas há, também, instrumentos intangíveis, como o parecer de um especialista, a mensagem escrita de um autor, a recomendação verbal de um amigo, ou o hábito de trocar informações, bens e serviços entre pessoas para quem a simples promessa tem a força de um contrato. 


\section{O MERCADO E O DESENVOLVIMENTO}

Se a visão do mercado que defendemos for aceitável, teremos que encará-lo sob enfoques mais amplos. Por exemplo, de mero palco ou cenário dos atos de troca ele terá que passar a participante ativo que desempenha determinados papéis de natureza social, econômica e cultural, inclusive o de agente do desenvolvimento de uma sociedade ou nação. É sob esse enfoque que queremos encará-lo a seguir, ao formular e defender sete hipóteses ou proposições que a outros pesquisadores possam eventualmente servir de estímulos e pontos de partida para investigações mais profundas e cientificamente consubstanciadas.

Destas hipóteses, a proposição básica, em torno da qual giram as outras, pode ser assim enunciada:

\section{P-1:O mercado é um potente catalisador do desenvol- vimento econômico, social e cultural de uma nação.}

Antes de entrarmos no mérito desta afirmação, convém tecer algumas considerações sobre o desenvolvimento, como aqui o entendemos. Aproveitamos para isso um trabalho nosso anterior, que partiu de vina preocupação semelhante àquela aqui enfocada, ou seja, de que os conceitos de desenvolvimento e subdesenvolvimento têm sido encarados sob ângulos demasiadamente restritos em relação à amplitude c complexidade de sua problemática (ver Richers, 1975).

Resumamos algumas das considerações básicas deste texto para orientar o presente artigo. São elas:

- Convém distinguir entre crescimento e desenvolvimento. Crescimento refere-se à evolução eminentemente econômica dos países desenvolvidos (PDs), que já atingiram elevado grau de prosperidade, mas precisam manter certo ritmo de progresso para não sofrerem recessões profundas. Para eles, a problemática do crescimento gira em torno de problemas como manutenção de alto nível de emprego, a formação adequada, mas não excessiva, de capital, busca do equilíbrio entre a relação poupança-renda, conservação de uma taxa cambial estável, ou seja, todos os problemas são voltados à conservação de um nivel de prosperidade já atingido.

Para os PMDs (países menos desenvolvidos) a situação é bem outra: precisam desenvolver-se porque o nível de vida de uma parcela elevada da sua população deixa (muito) a desejar. Ademais, nestes países, as oportunidades de desenvolvimento econômico dependem, em boa parte, de mudanças sociais, culturais e políticas.

- Para nós, o âmago da problemática do subdesenvolvimento e de sua superação gradativa consiste em descobrir meios para entrosar as populações marginalizadas nos processos de modernização que conduzem ao bem-estar material, no sentido que, de um lado, as capacitem a oferecer contribuições produtivas crescentes a esses processos $\mathrm{e}$, de outro lado, lhes abram caminhos para poderem usufruir das vantagens da modernização, tanto em termos econômicos, quanto sociais. Para que haja desenvolvimento, a intensidade ou taxa desse en- trosamento deve ser superior à taxa de crescimento demográfico da população marginalizada.

- O grau de desenvolvimento econômico de uma nação depende em parte da disponibilidade de recursos potenciais (como mão-de-obra qualificada, formação de capital, acesso às tecnologias, recursos naturais, etc.), mas sobretudo de um fator que provoca e comanda o processo de transformação desses recursos em insumos disponíveis para o crescimento. A esse fator damos o nome de ativação. Entendemos por ativação o processo comportamental que capacita e motiva pessoas a provocarem ou a participarem da transformação dos recursos potenciais em insumos disponíveis para os processos produtivos da sociedade.

- As variáveis que provocam maior capacidade e disposição ativacional não são mais relacionadas com fatores não-econômicos do que econômicos. Entre eles, destacamos os seguintes: o condicionamento físico e mental da população, e a internalização de conhecimentos, valores e atitudes antecipantes. Portanto, para que haja desenvolvimento, medidas destinadas à mobilização social, ao controle da natalidade e ao estímulo do know-how são pelo menos tão importantes quanto a geração de recursos naturais, tecnológicos e financeiros.

Aqui se aventa a hipótese (não abordada no texto mencionado) que o mercado seja um forte elemento ativacional para o desenvolvimento. Como tal, ele age à semelhança de um catalisador, ou seja, como se fosse um agente que tanto pode acelerar, quanto atrasar a reação entre as variáveis econômicas, sociais e mesmo culturais que interagem em uma sociedade em desenvolvimento.

Tudo que é transacionado numa sociedade passa pelo mercado, que funciona como uma enorme rede que não só capta e segura informações, produtos, serviços e valores em geral, como também os mistura, seleciona, classifica, refina, rejeita parcialmente, promove $\mathrm{e}$ por vezes até transforma. Todas as pessoas e instituições que participam desse processo e dele dependem para seus sucessos comerciais respeitam-no, pois ele tem poderes suficientes tanto para barrar as transações, como para acelerar a sua passagem.

Na medida em que um país cresce, a influência e o poder do mercado aumentam, não só no sentido horizontal, como também vertical. Por exemplo, ao longo dos processos de industrialização, não apenas maior quantidade e variedade de bens e serviços é transacionada no mercado, como surgem novas formas de negociação, como o mercado de capitais, de commodities, de tecnologia, de mão-de-obra especializada, de eventos esportivos e culturais, de transporte $e$ armazenagem, etc.

Em sua essência, a função catalisadora do mercado consiste em exercer um papel de mediação entre os "partidos" - os vendedores e compradores - que, para satisfazerem seus objetivos, necessitam uns dos outros, mas partem de posições essencialmente conflitivas. A figura 1 descreve este relacionamento e seus conflitos inerentes. De um lado, temos os indivíduos que desejam comprar e consumir bens, serviços ou outros valores e, do outro lado, temos as empresas produtoras 
Pessoas, famflias e grupos (de consumidores)

Mercado

Empresas e instituiçōes produtoras e distribuidoras

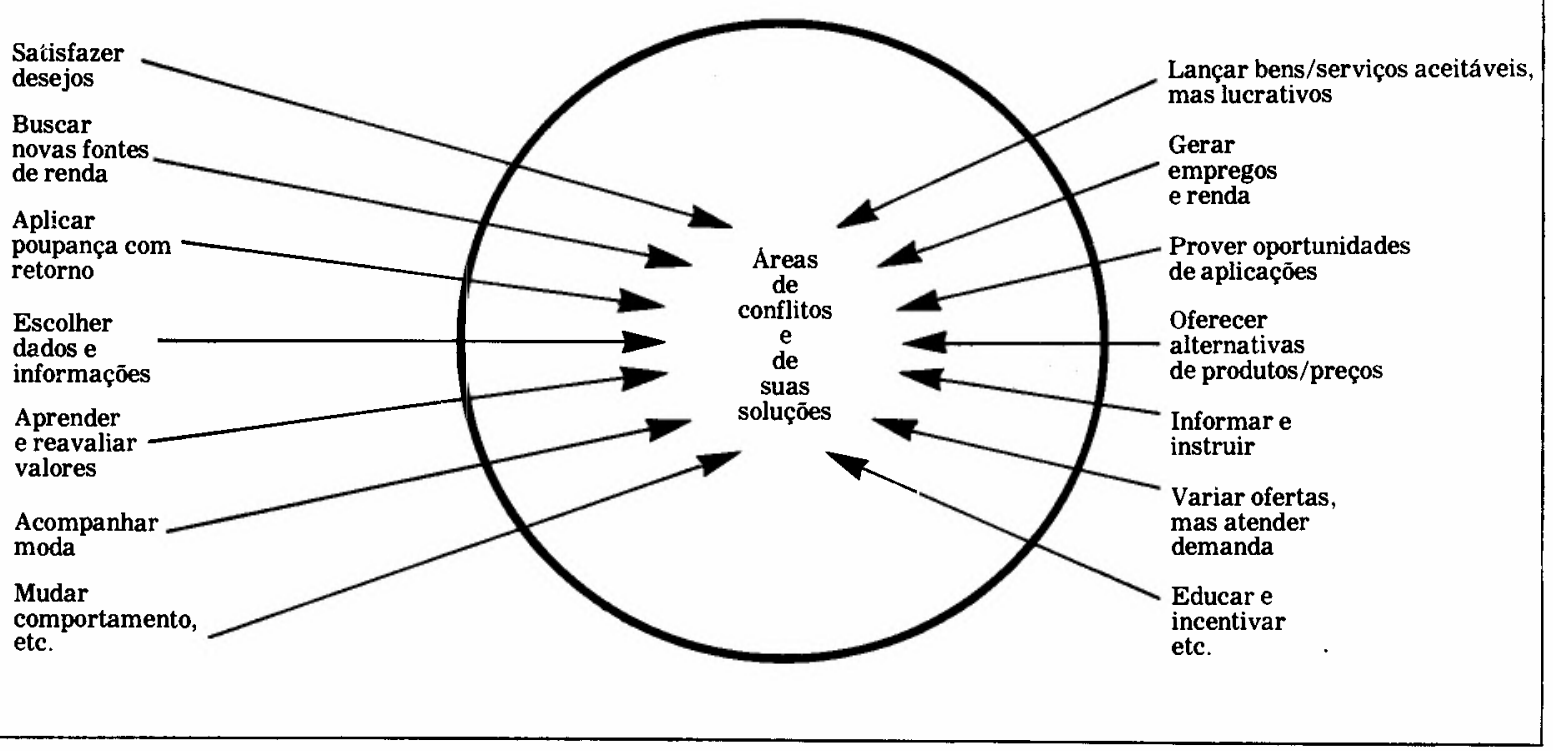

e distribuidores que se propõem a atender a demanda dos consumidores, mas sempre sob certas condições potencialmente divergentes e conflitivas. Assim, por exemplo, um consumidor procura determinado produto no mercado e dispõe-se a pagar um preço $X$ após ter confrontado várias ofertas semelhantes de vários ofertantes dispostos a atender a esta demanda, a preços distintos, mas todos com a expectativa de lucrar com a transação. Tanto o confronto entre os produtos competitivos, quanto a troca em si só se tornam possíveis dada a existência de um mercado que age como mediador entre as partes.

Através da função catalisadora, o mercado ativa o desenvolvimento, agindo em várias frentes e atraves de uma multiplicidade de instrumentos. Por exemplo:

- ele ajuda a moldar os nossos valores e hábitos (ver hipótese P-2 a seguir);

- ele constitui um padrão do progresso individual, social e institucional (hipótese P-3);

- ele facilita a solução de conflitos, tanto internos dos compradores e vendedores potenciais, quanto entre concorrentes e entre parceiros dos atos de troca (hipótese P-4);

- ele exerce as funções de agente regulador e multiplicador de informações e processos de troca (hipótese P-5);

- ele facilita e acelera os processos de percepção e discernimento de produtos/serviços que surgem no mercado (hipótese P-6);
- ele aproxima os estratos sociais e contribui para o maior nivelamento de seus hábitos e costumes (hipótese P-7).

É o conjunto destas atribuições que qualificam o mercado como um poderoso agenciador do desenvolvimento.

\section{OMERCADO COMO MOLDADOR DE VALORES}

A maneira como o mercado atua para exercer esta função catalisadora ainda requer uma multiplicidade de estudos. Mas, a título de primeiro incentivo à investigação, podemos sugerir algumas proposições, como as que se seguem:

\section{P-2: O mercado exerce (forte) influência sobre a formação dos nossos valores e hábitos (tanto como pessoas, quanto como consumidores)}

Valores são as convicções que orientam o nosso comportamento; os hábitos formam a nossa disposição de repetir determinados tipos de comportamentos em situações semelhantes. A maioria dos nossos valores é adquirida durante a nossa infância, enquanto os hábitos são formados ao longo da vida, porque neles incorporam-se também as principais experiências. Desenvolvemos nossos valores e hábitos através de um processo consecutivo de aprendizagem, que pode ser cognitivo (através da percepção de estímulos) ou afetivo (através da apreciação destes estímulos). ${ }^{9}$ Tanto a adoção de um valor ou de uma idéia, quanto a compra de um produto ou serviço implicam um processo de apren- 
dizagem que atravessa os cinco estágios da difusão de inovações antes de se concretizar.10

É claro que o indivíduo quase nunca se conscientiza deste processo evolutivo de adoção de valores e hábitos. No entanto, ele costuma registrar uma parte de suas impressões em sua memória, à qual recorrer quando delas necessita. Assim, por exemplo, o consumidor típico procura colocar em ordem todas as informações pertinentes sobre produtos adquiridos e suas reações ao seu consumo, através de um esforço inconsciente de não só associar determinadas ações com determinadas conseqüências, como também de classificar produtos comparáveis por categorias capazes de satisfazer suas necessidades em maior ou menos escala. ${ }^{11}$ Ele sabe, por exemplo, que, de uma oferta de seis ou dez produtos de consumo não-duráveis, a marca $X$ reúne várias características identificáveis que, em seu conjunto, satisfazem-no mais do que as dos outros produtos. É provável também que, como consumidores, não só nos esforcemos para memorizar e classificar os bens, como também procuremos colocá-los dentro de uma hierarquia de prioridades diretamente associada ao nosso sistema de valores.

Ao que parece, esse sistema abrange três categorias, a saber: os valores básicos de nossa formação de personalidade (como o auto-respeito e a liberdade de escolha), os valores genéricos de consumo (como os princípios de que determinados produtos devem ser antipoluentes ou facilmente reparáveis) e, finalmente, as convicções referentes a atributos dos próprios produtos (como sua cor, resistência ou seu preço). Esses atributos constituem os elementos básicos para determinar as atitudes dos indivíduos em relação aos produtos e serviços em geral. Eles são derivados, em parte, do nosso sistema de valores e, em parte, da nossa experiência como consumidores. 12

Ao tentar identificar as origens que provocam mudanças neste sistema de valores, tantos os psicólogos, quanto os sociólogos e antropólogos pouco se preocupam com as influências de ordem institucional. Concentram sua atenção em fenômenos sociais (como pais, líderes de opinião ou grupos de influência, em traços culturais (como costumes e linguagens) e variáveis psicossomáticas (como motivações e atitudes). Suspeitamos, todavia, que, além destas dimensões, haja outras que exerçam influência respeitável sobre o nosso comportamento.

O mercado é para nós uma destas dimensões. Ele provavelmente exerce influência intensa sobre o nosso comportamento, porque a ele nos dirigimos continuamente para esclarecer dúvidas e para satisfazer desejos, não só materiais, como também psicológicos e culturais. Para poder $u s a ́-l o$ adequadamente, precisamos compreendê-lo e acompanhá-lo ao longo do tempo e espaço. Isto requer esforços, e a disposição de aprender e mudar.

Com grande freqüência, usamos o mercado como fonte de referências para orientar não só nossas compras mais ou menos rotineiras, como também para nos auxiliar na busca de novas modalidades de consumo. ele não só nos informa sobre novas ofertas, seus preços e vantagens diferenciais, como nos instiga a testar novas formas de consumir e de nos comportar socialmente. Assim, induz-nos a mudar nossos hábitos, a adotar novas modas e griffes e a exercer influências sobre nossos parentes, amigos e companheiros sempre que nos consegue convencer das vantagens de alguma inovação. Ademais, ele oferece-nos opções para o uso de produtos e serviços que vêm ao encontro da nossa busca de prestígio e status social, além de ser freqüentemente responsável, ao menos indiretamente, pela frustração que resulta de um dinheiro mal-aplicado ou pela alegria da descoberta de um novo tipo de entretenimento. É provável até que ele contribua sensivelmente à formação dos mitos familiares e pessoais que fazem parte do nosso acervo cultural. ${ }^{13}$ Tudo isto não é possível sem que o nosso sistema de valores seja profundamente afetado.

É verdade que nem todos nós somos igualmente suscetíveis às influências do mercado. Provavelmente, à medida que avançamos em idade, a influência tende a diminuir, ou seja, a geração mais facilmente influenciável pela força exógena do mercado deve ser a dos adolescentes. É provável também que o grau de influência varie de acordo com as classes sociais, bem como o sexo, devendo ser a mulher mais perceptiva às mudanças do que o homem. As camadas médias devem ser mais receptivas às influências externas do que as camadas abastadas, dada sua maior ânsia de progredir e de atingir posições sociais mais elevadas. Mesmo assim, ninguém escapa do poder de influência das forças do mercado, pois todos somos mais uu menos dependentes das crenças e dos valores do estrato social a que pertencemos.

Poder-se-ia argumentar que não é o mercado o principal poder gerador das influências, mas antes as empresas que a ele encaminham os seus produtos e serviços, além da sociedade como um todo que os avalia e aceita ou não. No entanto, nada aconteceria sem a intermediação do mercado que, por atrair uma multiplicidade de compradores potenciais de um mesmo tipo de bens, mas oferecidos por vários produtores competitivos entre si, permite a realização da massificação de bens e serviços, tão característica das sociedades industrializadas do nosso tempo. O produtor beneficia-se do mercado, porque este lhe oferece a condição de comprovar as vantagens da sua oferta, através do confronto entre produtos substitutivos. O consumidor dirige-se ao mercado, porque lhe porporciona uma variedade de opções e a possibilidade de obter melhor relação preço/quantidade, além da oportunidade de "descobrir" novos produtos e usos.

Assim, a própria condição do mercado, de reunir uma multiplicidade de compradores e vendedores potenciais num só ambiente, permite que cada um e todos os membros dos dois partidos sejam influenciados pelo conjunto, não só em termos daquilo que irão vender ou comprar hoje e no futuro, como também com respeito aos seus valores e hábitos comportamentais e de consumo.

\section{O MERCADO COMO PADRÃO DO AVANÇO}

As considerações feitas conduzem-nos a uma outra hipótese, qual seja: 
P-3: O mercado é um dos mais requisitados padrões de comparação que pessoas, grupos sociais e instituições utilizam para a aliar (conscientemente ou não) no seu grau de progresso (e sucesso) econômico e social.

Progresso e sucesso são termos relativos; eles só fazem sentido se constituem um avanço em relação a um período e/ou estágio anterior. Por serem relativos, eles incitam contínuos esforços de comparação e mensuração do seu avanço. Em suma, eles exigum padrões.

A sociedade industrial moderna criou uma variedade de padrões como bases para a avaliação do sucesso e progresso, alguns quantificáveis, outros não. A título de ilustração, mencionamos o cargo de um executivo, as posses de uma família, o status social de uma pessoa, os diplomas e certificados dos estudiosos, o comportamento e as manifestações de líderes de opinião, os recursos e rendimentos de uma empresa e as cotações de suas ações nas bolsas, os seus balanços, a freqüência em que são citadas em revistas e jornais e uma infinidade de outros.

Grande parte destes padrões emana do mercado e utilizam-no como referencial. Assim, por exemplo, as empresas fazem do mercado a vitrina de seus produtos, o campo de suas pesquisas externas e de divulgação e avaliação de suas mensagens. Ademais, medem uma boa parte de seus resultados através do mercado, seja em termos de cobertura geográfica, de penetração por segmentos e de participação em confronto com seus principais concorrentes, seja através de medidas menos tangiveis como a lealdade de seus clientes e a sua imagem institucional.

Para o indivíduo, o mercado é um padrão para nortear suas compras, para confrontar preços e tipos de bens e para avaliar o grau de seu acompanhamento de tendências da moda e dos hábitos de consumo em geral. Mas o que mais lhe interessa como consumidor é o seu desejo de arrancar do mercado as melhores condições de aquisição e satisfação de necessidades, em relação ao que está em condições e disposto a gastar pelas mercadorias. Para tal, o seu padrão de sucesso é a tentativa (dificilmente mensurável, mas bastante real para quem a persegue) de otimizar a sua relação insumo/utilidade na compra de bens. O mercado, com sua variedade de opções, permite-lhe aproximar-se mais deste ideal.

No pragmatismo do dia-a-dia é quase impossível avaliar o impacto que estas variáveis exercem sobre nossa vida, seja como consumidores potenciais, seja como executivos responsáveis por uma área qualquer numa empresa. Portanto, é impossível estabelecerem-se padrões absolutos que norteiem a nossa ação econômica e social de maneira preeminentemente racional. Daí não ver eu outra maneira mais eficaz e simples do que usar o mercado como uma aproximação para estabelecer padrões do nosso comportamento. Na realidade, ela já é isto, apenas poucos se conscientizam desse fato e muito menos procuram tirar algum proveito.

Exemplifiquemos, para tornar a idéia mais clara: tanto o comprador quanto o vendedor operam com orçamentos mais ou menos precisos. Normalmente, suas principais bases para elaborar esses orçamentos são, de um lado, a experiência acumulada, e do outro lado, $o$ mercado, na expectativa de que ele lhe dâ alguma noção sobre o que poderá acontecer no futuro. Então, nós nos dirigimos ao mercado com o intuito de pesquisá-lo para que possamos estabelecer padrões de comportamento futuro, que, se não constituem regras intransponíveis, ao menos nos oferecem indícios mais aceitáveis para orientar a nossa ação, seja como membros de um estrato social, seja como consumidores.

O que se afirma, em suma, é que este esforço de busca de padrões junto ao mercado é uma constante mais ou menos consciente, exercida por todos os vendedores e compradores ansiosos em equilibrar os seus orçamentos e otimizar a sua relação custos/benefícios. Fazemos isto porque o mercado constitui de longe a fonte mais rica e objetiva de informações de que dispomos para avaliar a natureza do conflito e de seus possíveis efeitos atuais e futuros, seja como indivíduos e consumidores, seja como produtores ou distribuidores.

\section{PONDERAÇÕES SOBRE O CONCEITO DE CONFLITO}

Não há evolução sem conflitos. Tanto as mutações biológicas, quanto os processos de mudança social e de crescimento econômico, ou mesmo o despertar de uma criança ao longo da sua maturação, são inconcebíveis sem forte dose de tensão conflitiva.

Conflitos surgem pelos mais diversos motivos. Em alguns casos, grupos separam-se de outros grupos para manifestar sua divergência ideológica ou política e assim provocam o conflito; em outros casos, o conflito processa-se na intimidade da própria pessoa que hesita, em função de dúvidas, quanto ao caminho a tomar. Portanto, o conflito, como o teatro, obrigatoriamente encerra três elementos: a controvérsia em torno de um temário ou objeto, um ou vários atores que participam da controvérsia, e um palco em que esta é encenada.

Há uma infinidade de palcos, como a célula de um ser orgânico, a parsonalidade de um indivíduo, a família, grupos sociais, partidos políticos, parques públicos, o sistema bancário, países e continentes, e provavelmente até parcelas do universo. O mercado é um destes palcos. Mas, ao contrário de muitos outros, ele representa uma constante na sociedade moderna, mesmo nas que adotaram uma economia planejada. Isto significa que, a qualquer momento, qualquer pessoa pode dirigir-se ao mercado para buscar informações, testar a receptividade de um produto, desafiar um concorrente, confrontar valores, ou simplesmente observar os seus movimentos como mero espectador.

A grande maioria dos estudos dedicados à natureza dos conflitos em mercados foi preparada por economistas. Todos eles giram em torno de um só temário: a concorrência.

Insatisfeitos com esta visão limitada, cientistas sociais de outras áreas procuraram mudar o enfoque. Um exemplo destacável na área de marketing é a obra de Alderson (1457), que sugeriu que se substituísse o concei- 
to de demanda por oportunidade e o de oferta por esforço. Mas, ao definir estes dois conceitos ampliados, Alderson não conseguiu libertar-se o suficiente do viés dos próprios economistas que encaram ambos os conceitos sob o ponto de vista da empresa ofertante. Assim, para ele, a oportunidade "significa a demanda por um produto ou serviço específico que a empresa individual está preparada a providenciar", enquanto que o esforço consistiria nas "atividades que uma empresa exerce para servir seus mercados"' (p. 355-6).

Para nós, o conflito que se manifesta no mercado entre oferta e demanda não resulta apenas da rivalidade entre concorrentes que ambicionam aumentar sua fatia do bolo, mas inclui também as dúvidas que o consumidor tem ao designar uma parcela de sua renda à aquisição deste ou daquele bem, ao invés de guardá-la para o futuro. De alguma maneira, o egocentrismo, que caracteriza o homem e está presente em todas as suas ações, deveria fazer parte do conceito de conflito entre oferta e procura em análises econômicas do futuro. Não importa o que façamos como indivíduos ou instituições, só abrimos mão de algo se isto se justifica (ao menos aparentemente) à luz de uma retribuição que supera o sacrifício. E convém refletir sobre isso ao se tentar definir oferta e procura. Talvez uma concepção aceitável de oferta fosse o retorno que alguém (um indivíduo ou uma instituição) espera obter em troca de um valor (produto ou serviço) que se dispõe a ceder; enquanto que a demanda poderia ser caracterizada como beneficio (satisfação de um desejo) que alguém espera em troca de um sacrifício (como dinheiro, tempo, trabalho ou outro valor).

Visto sob esse enfoque, o equilibrio, de que falam os economistas ao tratarem da formação de preços no mercado, deveria trabalhar com quatro e não apenas duas dimensões, sendo duas internas, psicológicas aplicáveis a cada um dos lados, e as outras duas externas ou referentes à parte mais visível do conflito entre as partes. Assim, por exemplo, do lado da oferta não só seriam incluídas as variáveis custo e preço de produção, como também as opções estratégicas de se produzir determinado tipo de bem versus um outro, ou mesmo a opção de deixar-se de produzir ao todo em troca de um benefício de ordem social ou fiscal. Em contrapartida, no lado da demanda, não só a relação preço/qualidade que o consumidor está propenso a aceitar teria que ser levada em conta, como também as opções que o comprador tem, não somente em termos de substituir um produto por outro, mas também de deixar de comprar determinados bens em benefício do seu lazer. Por exemplo, ele talvez resolva trabalhar menos, abrir mão de uma parte de sua renda e da aquisição de alguns bens, porque o "ócio marginal" faz parte do seu sistema de valores.

Estas considerações obviamente aplicam-se mais a uma sociedade industrial avançada do que a um país em desenvolvimento como o Brasil, mas lá poderão tornarse obrigatórias como elementos de qualquer teoria econômica que procure interpretar o grau crescente de interdependência entre as variáveis de ordem material, psicossocial e cultural que caracterizará as sociedades pósindustriais.

\section{O MERCADO COMO CONCILIADOR DE CONFLITOS}

Como no teatro, o palco do mercado serve para manifestar, contrapor, confrontar e possivelmente resolver os conflitos trazidos pelos atores. Cada um deles é investido de maior ou menor parcela de poder que resulta da interface das seguintes quatro variáveis: primeiro, do número de atores que surgem de ambos os lados (oferta e procura) em relação ao vulto do negócio a ser transacionado; segundo, dos recursos (como informações, dinheiro, estoques, acesso ao mercado de capitais, etc.) de que cada um dispõe e que lhe dá maior ou menor fôlego para agüentar pressões adversas; terceiro, da disposição psicológica de cada um para permanecer no jogo durante mais ou menos tempo; e, quarto, da maneira (em larga escala incontrolável por cada um dos participantes) como essas três variáveis interrelacionam-se ao logo do processo de negociação. in

A negociaçãoé a forma mais difundida para resolver os conflitos que surgem no mercado. Como bem ressalta Alderson (1957), a negociação, no sentido do marketing, é bem mais do que um método para realizar transações. Para ele, "negociação é a forma de relacionar dois sistemas entre si" e, como tal, "é a manifestação da articulaão competitiva ou do esforço de vários participantes num processo como o marketing para organizar o processo em prol de sua própria vantagem.

Por se tratar de um sistema, podemos entender negociação num sentido bem amplo; ele não só se refere ao relacionamento entre compradores e vendedores potenciais, como também às rivalidades entre concorrentes, tanto ao lado da oferta, quanto da demanda e, finalmente, conclui também as tentativas dos conflitos internos, a que nos referimos, ao discutir os conceitos de demanda e oferta. Negociação, neste sentido extenso, é a tentativa formal e mesmo inconsciente de resolver conflitos de qualquer natureza, em que o mercado participa como cenário ou palco de ação.

O enunciado de nossa quarta proposição parte de considerações como as formuladas ao constatar:

\section{P-4: As tentativas de buscas e fechamento de contratos e negócios nos mercados exercem uma influência bem mais acentuada no comportamento dos atores (vendedores e compradores potenciais) do que a realização dos negócios em si.}

Por que isto seria assim? As razões são duas. Primeiro, porque apenas uma fração das negociações e tentativas de soluções de conflitos resultam em trocas efetivas. Segundo, porque as falhas nas negociações geram reações psicológicas muito mais profundas e duradouras do que as transações efetivas. É sobretudo este segundo aspecto que mereceria investigações bem mais profundas que aquelas até agora realizadas nos meios acadêmicos. A maioria dos estudos realizados a respeito do mercado encara-o como um elemento passivo e estático no processo de trocas. Raros são os que procuram investigar de que maneira o mercado influencia as transações, por exemplo, como fonte de informações para os partidos envolvidos, ou como padrão de com- 
portamento, como já assinalamos. Basta lembrar que, para se realizar determinado negócio, quase sempre múltiplos contatos são necessários, que freqüentemente não só envolvem o produtor e o consumidor, como também um ou alguns intermediários que participam ativamente do processo de negociação e da transferência de posse. Ademais, para atrair compradores ao mercado, várias modalidades de comunicação costumam ser utilizadas pelos ofertantes, tais como publicidade, promoção de vendas e esforço de venda pessoal.

Os órgãos de comunicação que geram as mensagens publicitárias, por sua vez, dependem da investigação mais ou menos sistemática dos motivos e hábitos de compra que procuram interpretar e transformar em argumentos de venda. Numa sociedade voltada à livre iniciativa, a preexistência de um espírito competitivo estimula este tipo de relação entre pesquisa e comunicação, para assegurar que o público comprador tenha sempre opções à sua disposição, entre produtos competitivos e possa escolher aquele que mais se aproxime de suas expectativas.

Se fosse mensurável, o grau de sucesso de um mercado deveria ser avaliado menos pelo número ou valor das transações efetivamente realizadas, do que pela relação entre o número de tentativas de troca e o número de negócios fechados. Assim, por exemplo, a administração de um shopping center aponta com orgulho que o faturamento aumentou em alta proporção em relação a períodos anteriores, mas dificilmente se preocupa com questões vitais para o sucesso do centro, tais como: quais são os motivos que levaram as pessoas ao centro, até que ponto estes motivos foram induzidos e de que maneira? O que aconteceu antes e durante as visitas em termos de dúvidas e conflitos com respeito a locais de compra, tipos de produtos a serem eventualmente adquiridos, expectativas de preços e planos de financiamento, tipos de estabelecimentos varejistas, grau de necessidade dos produtos, modalidades de sua utilização, etc.? Que tipos de informações os compradores potenciais procuraram obter antes e durante a visita para lançar luz sobre essas dúvidas? Quantas pessoas realizaram visitas, não com o intuito de comprar, mas com a finalidade de pesquisar, confrontar, divertir-se ou colher dados? Quantas delas foram induzidas no local para concretizar uma compra? Finalmente, e acima de tudo: que ensinamentos as pessoas conseguem derivar de experiências específicas que as coloquem em contato com o mercado e que lhes possam ser úteis em futuras situações comparáveis?

A insegurança que resulta de respostas inadequadas a este tipo de perguntas faz com que tanto as pessoas, quanto as instituições fiquem num estado de aler$\mathrm{ta}$, antes de proporem a realização de uma compra ou venda. A sua decisão é lenta, ou melhor, precedida por um processo que poderia ser denominado "tatear o mercado".

A figura 2 resume o que tenho em mente ao falar sobre o esforço de tatear o mercado. Este sempre envolve os dois lados da negociação, tanto os compradores quanto os vendedores. Ambos têm intuitos semelhantes ao tentar dirimir suas dúvidas, se bem que as perguntas que formulam e procuram responder sejam diferentes. Esses intuitos consistem em: reduzir incertezas, buscar informações, confrontar opções (de compra ou venda) e resolver o conflito. Tanto compradores como vendedores só atingem este último estado (e mesmo assim nem sempre de maneira satisfatória) quando conseguem completar uma transação, mas logo surgirão novas necessidades ou oportunidades para reiniciar o processo.

A condição de tatear o mercado é, portanto, uma condição inescapável e contínua, tanto para os indivíduos que procuram satisfazer seus desejos, como consumidores, quanto para as empresas que, para sobreviver e crescer, precisam adaptar-se ao mercado. Mas muitas falhas que acompanham esse processo certamen-

Figura 2

O tatear do mercado implica:

\begin{tabular}{|c|c|c|}
\hline Por parte dos indivíduos (compradores) & Intuitos & Por parte das empresas (vendedores) \\
\hline $\begin{array}{l}\text { O Produto é bom? } \\
\text { Preço compensa? } \\
\text { Quc benefícios traz? } \\
\text { Tenho os meios? } \\
\text { Compro ou nāo? }\end{array}$ & $\underset{\substack{\text { Reduzir } \\
\text { incertezas }}}{\downarrow}$ & $\begin{array}{l}\text { O Produto é adequado ao mercado? } \\
\text { Há demnada suficiente? } \\
\text { O preço é atraente? } \\
\text { O MIX é racional e eficaz? } \\
\text { Quem sāo os concorrentes e como agem? }\end{array}$ \\
\hline $\begin{array}{l}\text { Com quem se informar? } \\
\text { A publicidade é confiável? } \\
\text { O ponto de venda é o melhor? } \\
\text { Convém consultar alguém antes? }\end{array}$ & $\begin{array}{c}\downarrow \\
\text { Buscar } \\
\text { informaçōes }\end{array}$ & $\begin{array}{l}\text { Qual é o potencial de mercado? } \\
\text { Compensa testar o mercado? } \\
\text { Onde, quando e como distribuir e promover? } \\
\text { Como reagirá a concorréncia? }\end{array}$ \\
\hline $\begin{array}{l}\text { Há ofertas (ou lojas) mais em conta? } \\
\text { Há substitu tos melhores? } \\
\text { Quais as formas de financiam en to? } \\
\text { Conviria adiar decisão? }\end{array}$ & $\begin{array}{c}\underset{\text { Confrontar }}{\text { opções }} \\
\text { d }\end{array}$ & $\begin{array}{l}\text { Seria melhor mudar, desenvolver mais ou abandonar a linha? } \\
\text { A demanda é elástica? } \\
\text { Convém mudar apresentação e/ou preço? } \\
\text { Convém mudar sistemas de venda, distribuiçāo e promoçāo? }\end{array}$ \\
\hline $\begin{array}{l}\text { Comprar } \\
\text { Usar } \\
\text { Satisfazer } \\
\text { (Nāo) repetir compra }\end{array}$ & $\begin{array}{c}\downarrow \\
\text { Resolver } \\
\text { conflito }\end{array}$ & $\begin{array}{l}\text { Lançar ou retirar } \\
\text { Abaixar (aumentar) preço } \\
\text { Ampliar (reduzir) número de pontos de venda } \\
\text { Promover mais (menos) }\end{array}$ \\
\hline
\end{tabular}


te devem deixar marcas profundas no comportamento, seja das pessoas, seja das instituições, a ponto de não só influenciarem os seus comportamentos futuros, como também de buscarem modalidades que venham a simplificar e aumentar as probabilidades de sucesso em negociações futuras. O que os autores aprendem, ao adquirir maior experiência nesse jogo, contribui para desenvolver e refinar seus valores e sua capacidade de formulação de diretrizes, e contribui também para exercer uma influência (didática) sobre terceiros, como filhos, amigos, companheiros de trabalho, subordinados e outras pessoas com que mantemos contatos. Mas, por mais rica que seja nossa experiência, jamais conseguimos traduzi-la em equações ou regras simples de comportamento, porque o mercado é dinâmico, possivelmente até volúvel, o que requer contínuas reavaliações e adaptações comportamentais.

Assim, ele nunca deixa de ser uma escola para quem com ele se relaciona.

\section{OMERCADO COMO REGULADOR E MULTIPLICADOR DE INFORMAÇÕES}

Um dos principais desafios de uma sociedade em desenvolvimento consiste em descobrir meios para tirar melhores proveitos de seus recursos, respectivamente de reduzir os desperdícios na exploração econômica destes recursos, sejam eles naturais, humanos, tecnológicos, financeiros ou outros. Ao menos em termos relativos, os desperdícios costumam ser substancialmente mais elevados nos PMDs do que nos PDs.

Curiosamente, onde os recursos são particularmente abundantes, o desperdício tende a ser maior, porque a população não lhes atribui valor. Bons exemplos são: extensas áreas cultiváveis, matas virgens, amplas reservas minerais. A falta de experiência, de preparo técnico, de know-how ou mesmo de instrução básica contribui para que essas fontes de riqueza não sejam devidamente apreciadas. mas, na medida em que os processos de produção e de troca de um país tornam-se mais complexos, a população apercebe-se de seus valores naturais e, com isso, surge maior conscientização das vantagens da racionalização dos mecanismos produtivos e distributivos. $\mathrm{O}$ mercado provavelmente tem muito a ver com isto, a ponto de afirmarmos:

\section{P-5: O mercado é o principal agente regulador e multiplicador de informações nos processos de troca.}

Todos os mecanismos de troca envolvem tentativas repetidas de aproximação e distanciamento entre os atores que buscam a troca. Não só a freqüência e a intensidade com que se processam esses contatos, como também a busca de oportunidades de troca em termos de locais, horários ou momentos psicológicos implicam a necessidade da presença de um mercado. por exemplo, o que um hortifrutigranjeiro faria para vender os seus produtos, e o que a dona-de-casa faria para encontrá-los, não fosse a feira? Ou mesmo, o que um autor e seus leitores fariam se não houvesse editoras e livrarias?

Para ser eficaz na sua função de intermediar posições entre os atores, o mercado precisa ser continuamen- te alimentado com informações que permitam aos participantes se encontrarem.

Efetivamente, o mercado costuma ser uma riquíssima fonte de informações. Ele não só nos informa sobre as oportunidades de troca nele presentes, como facilita também a aproximação física entre os partidos; oferece condições para uma variedade de escolha, permite confrontar preços e modalidades de pagamento, além de ser um pólo de distribuição física, de armazenamento e de logística, bem como de comunicação verbal e eletrônica, graças à presença de vendedores, promotores de venda, informantes, degustadores, escritórios de serviços, sem falar das várias redes de comunicação eletrônica de que se utilizam a propaganda e a promoção, como o televisor, o rádio, o telefone, o telex, o computador e o videoteipe.

Ao informar, o mercado contribui também para a educação das pessoas que se utilizam de seus insumos para confrontar valores, buscar novas opções, experimentar produtos, transmitir suas impressões a terceiros e debater suas experiências. Assim, ele desenvolve o que antes denominamos "espírito seletivo" do consumidor, qual seja, sua atitude crítica em relação aos produtos oferecidos no mercado, à medida que progride socialmente e desenvolve sua capacidade de discernimento. ${ }^{15}$

Ao crescer, uma economia e seus mercados desenvolvem uma série de padrões comportamentais que passam a fazer parte dos estilos de vida da população e permitem a padronização de produtos, o que, por sua vez, contribui sensivelmente para a criação de economias de escala, não só na área de produção, como também com respeito à embalagem, distribuição, estocagem, ao transporte, ao uso de marcas e logotipos, à comunicação visual, rotulagem e ao atendimento da clientela nos pontos de venda.

Os reflexos desta padronização não são apenas econômicos, mas também psicossociais, no sentido de induzirem a criação e adoção de linguagens comuns entre os participantes dos processos de troca, e de criarem hábitos de consumo que atravessam as tendências sazonais e os ciclos de moda, e que ultrapassam as fronteiras regionais. Aos poucos, esses hábitos integram-se à sociedade e induzem-na a comportamentos mais racionais e voltados para a utilização econômica de seus recursos.

Os ganhos de escala não se restringem, portanto, às áreas de produção e distribuição; eles beneficiam também os atos decisórios de uma sociedade em desenvolvimento, como, por exemplo, ao instalar um supermercado num ponto de alta concentração urbana, ou ao montar um sistema de comunicação que liga os produtores aos seus distribuidores e consumidores. Tudo isto implica um processo de aprendizagem em que o mercado exerce a múltiplas funções de coletar, processar, monitorizar, expor e sobretudo difundir informações sobre o que está acontecendo na economia.

\section{O MERCADO COMO FONTE DISCERNIDORA PARA O CONSUMO}

O ato de comprar e consumir só raras vezes é mecânico e rápido; na maioria das situações, envolve um encadea- 
mento de passos que conduzem (ou não) à decisão. Esses passos costumam ser os seguintes: 1 . a predisposição ou a vontade de consumir, acompanhada de um conflito suore se se deve comprar ou não; 2 . a busca deopções de compra que procura diminuir o conflito; 3. a avaliação das opções de compra; 4. a escolha de uma das opções (ou o abandono); 5. a reação ou a busca da satisfação esperada. ${ }^{6}$

Este processo nunca é simples e requer um preparo do consumidor, que o envolve num intenso esforço de aprendizagem para desenvolver sua capacidade de discernimento, ou seja, o tirocínio de conseguir diferenciar entre produtos que efetivamente atendem as suas necessidades e os demais. Não apenas anos de treinamento são necessários para refinar esta capacidade, como é preciso também que a pessoa seja preparada de casa para poder enfrentar os problemas e desafios como cidadão-consumidor.

Numa sociedade em desenvolvimento este processo é lento, não só potque depende da formação de um sistema de valores modernizantes, como também porque a variedade de produtos disponíveis no mercado é limitada. Esta dificuldade, por exemplo, explica por que as pessoas das camadas humildes dos PMDs desperdiçam comida, têm dificuldade de cofrontar valores reais de produtos competitivos e deixam-se impressionar mais pelos aspectos do que pelos valores intrínsecos dos produtos. É bem mais fácil avaliar a capacidade de movimentação de uma motocicleta do que o valor nutritivo da alface.

À medida que um país amplia e diversifica a gama de seus produtos, deve ocorrer o que resumimos nas seguinte proposição:

\section{P-6: O mercado ajuda o consumidor a desenvolver sua capacidade de discernimento de produtos e serviços}

A aceitação ou compra de um produto/serviço no mercado pressupõe três condições por parte do consumidor: 1. recursos monetários ou poder aquisitivo suficiente para adquirir o produto; 2 . desejo (latente ou expresso) de possuí-lo; 3 . aquilo que poderíamos chamar de percepção significatória do produto ou PSP.

Nos estudos que versam sobre a evolução dos PMDs, a primeira destas três variáveis tem sido de longe a mais comentada, enquanto que a segunda é normalmente tida como algo existente em todas as camadas da população, mas largamente insatisfeita dadas as limitações do poder aquisitivo. A terceira variável parece não ter recebido nenhuma atenção. Vamo-nos concentrar nela, portanto.

Inicialmente, convém lembrar que, para nós consumidores, os produtos representam muito mais do que meros objetos utilitários. Nós nos envolvemos com os produtos em função das atitudes e dos valores que constituem o nosso ego. ${ }^{17}$ Por exemplo, não basta constatar que um automóvel não é apenas um meio de transporte para determinada pessoa, mas também uma forma representativa de seu status. É preciso também compreender se a representação de seu status faz parte do seu sistema de valores, o que não é necessariamente o caso. A partir do nosso grau de envolvimento, atribuímos maior ou menor importância aos produtos.

Nos EUA foram conduzidos diversos estudos que relacionam a importância que o indivíduo atribui ao produto com variáveis de decisão. Foram encontradas correlações bastante elevadas, não só com fatores evidentes, como os custos e os preços dos produtos, mas também com variáveis como o potencial de um produto de causar danos, o grau de dependência do produto percebido pelo consumidor, o impacto da comunicação face a face, a intensidade da busca antes de realizar a compra, etc. (ver Bloch \& Richins, 1983.)

Destas pesquisas é que derivamos o conceito PSP, ou percepção significatória do produto, que procura expressar o grau de percepção que um indivíduo (ou mesmo um grupo formado por indivíduos com valores e comportamentos comparáveis) tem para se conscientizar da utilidade de um bem ou serviço. Ela não só requer a habilidade de confrontar tipos e marcas competitivas e de avaliar os seus potenciais benefícios ou danos, como exige também a capacidade de atribuir valores aos bens em si, mesmo antes de testá-los, seja através de associação com experiências anteriores, ou por meio da capacidade de discernimento.

É provável que, numa sociedade em desenvolvimento, o nível do PSP seja muito baixo no início dos processos de industrialização e de modernização, mas se desenvolva a partir desses processos. Possivelmente as variáveis que maior influência exercem sobre a evolução do PSP incluem o convívio familiar, a influência das escolas e instituições religiosas, o sistema de comunicações e o próprio mercado. Cada uma dessas instituições contribui para induzir consumidores a testarem novos produtos, manifestarem-se a respeito das experiências com seus usos, a confrontarem produtos substitutivos e com isto desenvolverem maior capacidade, não só para diferenciá-los entre si, como também para incluir uma gama cada vez maior de produtos e serviços no seu cabedal de conhecimentos e de hábitos de consumo.

Podemos inferir algumas conclusões preliminares destas considerações, a saber:

1. O consumidor envolvido é aquele que só realiza uma compra após a avaliação dos benefícios que vários produtos competitivos podem-lhe oferecer.

2. Para poder avaliar racionalmente, ele não só necessita de uma capacidade de julgamento intelectual e emocional adequada, como também de uma experiência anterior, que lhe permita confrontar ampla gama de bens, mesmo sem testá-los de novo. Ele recorre, para isto, à sua memória e aprendizagem anterior.

3. Aprender a consumir racionalmente não decorre apenas de uma multiplicidade de experiências com diversos bens de consumo, mas também de um treinamento induzido (pelos pais, professores ou outras pessoas influentes), condicionado, em larga escala, pelo ambiente social em que se desenvolve uma criança como consumidor. 
4. Decisivo para a evolução do processo racional de escolha de bens, por parte de uma pessoa em formação, é o desenvolvimento da sua capacidade de discernimento entre produtos que (ao menos hipoteticamente) é composta das seguintes duas variáveis:

A) do PSP ou da habilidade do indivíduo de avaliar quão significativo seria o consumo de determinado bem para satisfazer determinado desejo;

B) da sua capacidade de avaliar quais das variáveis de decisão de uma compra (como preço, localização do ponto de venda, conselho de terceiros, etc.) devem pesar mais na sua escolha.

5. Para usar seus escassos recursos materiais e financeiros racionalmente, os cidadãos de sociedades em desenvolvimento precisam passar por um processo de aprendizagem que inclui a internalização da capacidade de discernimento de bens e serviços.

6. Este processo é lento e intimamente associado ao ritmo com que evoluem as mudanças sociais. O mercado é uma das variáveis (além das escolas, as instituições religiosas, o Governo, as empresas, etc.) que mais pode contribuir para acelerar este processo.

\section{O MERCADO COMO PÓLO DE MUDANÇAS SOCIAIS}

Uma das preocupações centrais da política de desenvolvimento de qualquer PMD consiste em tentar reduzir os desníveis da sua distribuição de renda. Processos políticos de democratização fazem parte deste empenho, como também os incentivos nas áreas de educação, alimentação e planejamento familiar, sem falar dos esforços de industrialização destinados a absorver maior quociente de mão-de-obra.

Aqui também o mercado age mais como intermediário, do que como força primária. Mas, por ser praticamente onipresente numa sociedade industrializante, sua influência deve ser respeitável. Podemos, portanto, conjeturar:

\section{P-7: Através da ação do mercado, as camadas sociais aproximam-se e influenciam-se mutuamente.}

No seu meio social, o ser humano busca, acima de tudo, o reconhecimento ou prestígio dado a ele por outros, sejam eles parentes, amigos, colegas ou mesmo desconhecidos. ${ }^{18} \mathrm{Em}$ larga escala, o prestígio do indivíduo determina sua incorporação numa camada social. Antes de aceitá-lo, esta o avalia aîravés de variáveis como sua ocupação, o montante e a fonte de sua renda, o estilo e a localização da sua residência, bem como o grau de sua instrução. 19

Para que o prestígio funcione como meio de comunicação e mobilidade social, é preciso que ele se torne aparente. Daí a afirmação de Kahl (1957, p. 108): “O prestígio tende a ser atribuído antes através do comportamento de consumo do que da renda, já que somente o que pode ser visto pode ser julgado. Os padrões de consumo e as redes de interação estão intimamente ligados; as pessoas gastam o seu tempo de lazer com outras que compartilham de seus gostos e atividades recreativas, e elas aprendem novos gostos daquelas com quem se associam.

Boa parte desta interação realiza-se em ambientes mais ou menos exclusivos, onde pessoas com estilos de vida comparảveis se reúnem e interagem socialmente. Exemplos disso são as discotecas, festas familiares, recepções empresariais, congressos de profissionais e os clubes. Cada um desses núcleos é relativamente fechado, o que não impede, contudo, que seus membros ambicionem participar de outros núcleos que thes parecem auferir prestígio maior. É esta uma das razões por que uma sociedade vive em constante ebulição.

O mercado é um dos campos mais férteis para exercitar a busca de status e a mobilidade social, não só porque é amplo e versátil, ou porque oferece empregos e, com isso, maior acesso a bens de consumo, mas também porque não tem qualquer preconceito social. Todas as camadas sociais são a ele bem-vindas, desde que constituam consumidores potenciais. Basta observar o trânsito num dia de grande movimento num supermercado ou numa exposição como a Bienal: lá se congregam representantes de todas as camadas sociais, idades e grupos étnicos. A comunicação entre estas pessoas não é direta. Mas o próprio mercado estabelece elos de ligação através dos produtos que oferece e úii maneira como os apresenta, por meio de vitrinas, cartazes, ofertas especiais e sobretudo pela sua linguagem: um jingle, um slogan publicitário ou uma música popular que sensibiliza milhões são elos de ligação entre os estratos sociais, ao criarem e/ou fortalecerem valores e ideais que podem ser comuns aos diversos membros de uma sociedade, como o nacionalismo, a liberdade, a independência do jogo estatal e muitos outros.

A confraternização que é assim criada não elimina injustiças sociais, nem aumenta o poder aquisitivo das camadas subalternas, mas permite que seus membros compartilhem mais dos processos de inovação tecnológica e de evolução industrial, inicialmente talvez mais como espectadores, mas com a perspectiva de se tornarem participantes mais ativos, graças aos estímulos psicológicos e de aprendizagem que recebem, ao estabelecerem e manterem contatos com o mundo moderno.

Este processo de sensibilização e aproximação entre os diversos estratos sociais, que se concretiza em larga escala graças à existência e às atividades do mercado, é sutil e dificilmente mensurável. Supomos, no entanto, que ele represente uma força complementar respeitável nos processos de desenvolvimento econômico e de mudança social.

\section{CONSIDERAÇÕES FINAIS}

Este artigo propõe-se oferecer dois tipos de contribuição inter-relacionadas. Primeiro, ele sugere uma ampliação do conceito de mercado, mais condizente não só com as múltiplas funções que caracterizam as sociedades industrializadas, como também com os avanços realizados, nestes últimos decênios, pelas pesquisas sociais, sobretudo nas áreas relacionadas com o comportamento do consumidor. 
Em segundo lugar, explora-se a tese de que o mercado seja um poderoso elo de ligação entre as forças que geram e/ou contribuem para o desenvolvimento econômico e social de uma região ou nação. Formulamos sete hipóteses empíricas a respeito desta colocação, seja para prestar apoio à tese principal e qualificar a natureza das relações entre o mercado e o desenvolvimento, seja para apontar alguns caminhos para a realização de pesquisas voltadas à investigação formal das nossas e de outras suposições correlatadas.

1 A relação entre o mercado e o desenvolvimento é um tema que me acompanha desde os anos 70 . Ver nas referências bibliográficas alguns artigos a esse respeito.

2 Existe vasta literatura sobre a evolução e os impactos da Revolução Industrial, mas poucas são as obras que versam sobre suas repercussões no mercado. Uma louvável exceção a esta regra é o magnífico trabalho de Alfred Chandler (1977), que dedica um capítulo inteiro (o $7^{\circ}$ ) a este assunto.

3 Por exemplo, o sociólogo alemão Hans Albert (1967) afirma o seguinte: "Hoje existem apenas poucas formaçōes sociais duráveis, que não fazem parte, de alguma maneira, da rede das relações comerciais" (p. 267). De outro lado, Albert reconhece: "O mercado de bens e serviços chamados econômicos é um caso especial, se bem que indubitavelmente um caso extraordinariamente significativo"' (p.395).

${ }^{4}$ Schein (1971, p. 3) define socialização como sendo "o processo pelo qual um novo membro aprende o sistema de valores, as normas e os padrões comportamentais essenciais para a sociedade, organização, ou o grupo em que a pessoa está entrando".

Engel, Blackwell e Kollat (1978, p. 139) acrescentam a esta definição que a "socialização ocorre e é necessária, porque o indivíduo tem necessidade de participar num ambiente social", e que "o processo de socialização se realiza através da influência de vários grupos de referência".

${ }^{5}$ O conceito estilo de vida é relativamente novo (surgiu nos EUA na década de 60), mas hoje já ocupa posição destaca na pesquisa comportamental, aplicada sobretudo ao marketing. Um resumo desse conceito, conforme a opinião de Lazer, diz o seguinte: "Estilo de vida é um conceito sistêmico. Ele se refere às características ou distinç̋̃es na maneira de viver, no seu sentido agregativo e amplo, de uma sociedade como um todo ou de um segmento dela. Ele engloba os padrões que se desenvolvem e emergem da dinâmica de convivência numa sociedade. Estilo de vida, portanto, resulta de forças como a cultura, valores, recursos, símbolos, autorizações e sanções" (apud Wells, 1979 , p. 36).

${ }^{6}$ O livro de Zaltmann (1965) descreve com bastante clareza as relações entre aprendizagem, liderança e comunicação, bem como suas aplicações na área de marketing.

${ }^{7}$ No meu livro Rumos da América Latina, desenvolvimento econômico e mudança social (Richers, 1975) analisei minuciosamente estas relações.

${ }^{8}$ Em contrapartida, as relações das " variáveis psicossociais e biológicas e/ou genéticas" são praticamente desconhecidas, se bem que atualmente já haja muitos cientistas que se dedicam à sua pesquisa.
9 Obras clássicas nesta área são de Hilgard (1956), Rogers (1962) e Skinner (1953). Trabalhos mais recentes, dignos de menção, são de Nord e Peter, bem como de Rothschild e Gaidis (1981).

$10 \mathrm{Na}$ nomenclatura de Everett Rogers (1962), esses cinco estágios são: conscientização, interesse, avaliação, experimentação e adoção.

11 Um sugestivo modelo comportamental que relaciona valores e atributos percebidos de produtos foi desenvolvido por Gutmann (1982).

12 Estas teses são de Vinson e outros (1977), que conduziram um teste empírico para prestar-lhes mais credibilidade.

13 Em artigo premiado, Sidney Levy explorou e ilustrou a idéia de como mitos oriundos do mercado (nos sentido usado por Claude LéviStrauss) podem ser usados para melhor compreender e até projetar comportamentos humanos.

14 Poder-se-ia argumentar que o marketing tem como função básica equacionar e resolver os conflitos decorrentes de inter-relação entre estas quatro variáveis. Neste sentido, o marketing seria também um instrumento que busca otimizar as forças do poder de que uma empresa dispõe para atingir os seus objetivos externos.

15 Ver A emancipação do administrador mercadológico. In: Richers, R. coord. Ensaios de administração mercadológica. 2. ed., Rio de Janeiro, FGV, 1978. p. 15.

16 Analisei estas cinco fases no artigo $O$ enigmático mas indispensável consumidor (Richers, 1984).

$17 \mathrm{O}$ conceito de ego-envolvimento foi originariamente desenvolvido por Sherif (1980) e mais tarde utilizado por vários autores, para melhor compreender a maneira como atribuímos maior ou menor importância aos produtos como consumidores.

18 Para o pesquisador social pioneiro W.L. Warner, pessoas ou famílias podem ser encaradas como sendo uma totalidade à busca de seu prestigio pessoal, ou a atitude de respeito derivada das várias funções que a pessoa exerce numa comunidade (ver Warner, 1949, p. 19 ).

19 Tanto Warner (1949) como Hollingshead (1949) chegaram a desenvolver índices de caracteristicas de status à busca não só de methor compreensão das variáveis que determinam o prestigio social, como também da sua classificação e eventual mensuração.

\section{REFERENNCIAS BIBLIOGRÁFICAS}

Albert, H. Marktsoziolkogie und Entscheidungslogick. Luchterhand, Neuwied, 1967.

Alderson, W. Marketing behavior and executive action, a functional approach to marketing theory. Homewood, Richard D. Irwin, 1957.

Bloch, P.H. \& Richins, M.L. A tehoretical model for the study of product importance perceptions. In: Journal of Marketing, 47 (3) 1983.

Chandler, Jr., A.D. The visible hand, the managerial revolution im American business. Cambridge, Mass., Harvard University Press, 1977. 
Engel, J.E., Blackwell, R.D. \& Kollat, D.T. Consumer behavior. Hinsdale, The Dryden Press, 1978.

Gutmann, J. A means-end chain model on consumer categorization process. Journal of Marketing, 46(2) 1982.

Hilgard, E.R. Theories of learning. New York, Appleton-Century-Cofts, 1956.

Hollingshead, A.B. Elmstown's youth. New York, John Wiley \& Sons, 1949.

Kahl, J.A. The American class structure. Holt, Rinehart \& Winston, 1957.

Kotler, P. Administração de marketing, análise, planejamento e controle. São Paulo, Atlas, 1974. v. 1.

Prentice-Hall, 1984.

Marketing essentials. Englewoods Cliffs,

Lazer, W. Life style concepts in marketing. In: Toward scientific marketing. American Marketing Association, 1963.

Levy, S.J. Interpreting consumer mythology: a structure approach to consumer behavior. Journal of Marketing, v. 45.

Marshall, A. Economics of industry. 1.ed. (1949). London, Macmillan, 1982.

Narver, J.C. \& Savitt, R. The marketing economy, an analytical approach. New York, Holt, Rinehart and Winston, 1971.

Nord, W.R. \& Peter, J.P. A behgavior modifications perspective on marketing. Journal of Marketing, 44 (2).

Ouchi, W.G. The M-form society, how American teamwork can recapture the competitive edge. Mass., Addison-Wesley, Reading, 1984.

Richers, R. A emancipação do administrador mercadoçógico. 1961, ver: Richers, Raimar. Ensaios.

- Transformação social pela abertura de novos mercados. Revista de Administração de Empresas, 8 (27) 1968.
Desenvolvimento: um desafio social. $R e$ vista de Administração de Empresas, 10, (2) jun. 1970.

Considerações pouco ortodoxas sobre a função do consumo e suas implicações para os países menos desenvolvidos. Revista de Administração de Empresas, 2 (2) 1971.

Rumos da América Latina, desenvolvimento econômico e mudança social. São Paulo, Edgar Blucher, 1975.

coord. Ensaios de administração mercadológica. 2. ed., Rio de Janeiro, FGV, 1978.

O enigmático mas indispensável consumidor: teoria e prática. Revista de Administração, 19 (3) 1984.

Rogers, E.M. Diffusion of innovations, New York, Free Press of Glencoe, 1962.

Rothschild, M.L. \& Gaidis, W.C. Behavioral learning theory: its relevance to marketing and promotions. Journal of Marketing, 44 (2) 1981.

Schein, E.H. Organization, socialization and the profession of management. In: Kolb, D.A. et alii, coord. Organization psychology. Englewood, Clifss, PrenticeHall, 1971.

Sherif, C.W. Social values, atitudes and involvment of the self Nebrasca Symposium on Motivation. Lincoln, 1980 .

Skinner, B.F. Science and the human behavior. New York, The Free press, 1953.

Vinson, D.E.; Scott, J.E. \& Lamont, L.M. The role of personal values in marketing and consumer behavior. Journal of Marketing, 41 (2) 1977.

Warner, W.L. et alii. Social class in America. Science Research Associates, Chicago, 1949.

Wells, W.D., coord. Life style and psychographics. American Marketing Association, 1979.

Zaltmann, G. Marketing contributions from the behavioral sciences. New York, Harcourt, Brace \& World, 1965. 